IZA DP No. 9077

Is There a Penalty for Becoming a Woman?

Is There a Premium for Becoming a Man?

Evidence from a Sample of Transsexual Workers

Lydia Geijtenbeek

Erik Plug

May 2015 


\title{
Is There a Penalty for Becoming a Woman? Is There a Premium for Becoming a Man? Evidence from a Sample of Transsexual Workers
}

\author{
Lydia Geijtenbeek \\ University of Amsterdam \\ Erik Plug \\ University of Amsterdam \\ and IZA
}
Discussion Paper No. 9077
May 2015

\author{
IZA \\ P.O. Box 7240 \\ 53072 Bonn \\ Germany \\ Phone: +49-228-3894-0 \\ Fax: +49-228-3894-180 \\ E-mail: iza@iza.org
}

\begin{abstract}
Any opinions expressed here are those of the author(s) and not those of IZA. Research published in this series may include views on policy, but the institute itself takes no institutional policy positions. The IZA research network is committed to the IZA Guiding Principles of Research Integrity.

The Institute for the Study of Labor (IZA) in Bonn is a local and virtual international research center and a place of communication between science, politics and business. IZA is an independent nonprofit organization supported by Deutsche Post Foundation. The center is associated with the University of Bonn and offers a stimulating research environment through its international network, workshops and conferences, data service, project support, research visits and doctoral program. IZA engages in (i) original and internationally competitive research in all fields of labor economics, (ii) development of policy concepts, and (iii) dissemination of research results and concepts to the interested public.
\end{abstract}

IZA Discussion Papers often represent preliminary work and are circulated to encourage discussion. Citation of such a paper should account for its provisional character. A revised version may be available directly from the author. 


\begin{abstract}
Is There a Penalty for Becoming a Woman? Is There a Premium for Becoming a Man? Evidence from a Sample of Transsexual Workers ${ }^{*}$

We study the earnings of transsexuals using Dutch administrative labor force data. First, we compare transsexuals to other women and men, and find that transsexuals earn more than women and less than men. Second, we compare transsexuals before and after transition using worker fixed effects models, and find a fall in earnings for men who become women and a smaller rise (if any) in earnings for women who become men. These earnings patterns, which hold for annual as well as hourly earnings, are consistent with a labor market model in which workers are discriminated for being female and transsexual.
\end{abstract}

JEL Classification: J16, J24, J71

Keywords: $\quad$ transsexuals, gender, labor market outcomes, discrimination

Corresponding author:

Erik Plug

Department of Economics

University of Amsterdam

Roetersstraat 11

1018 WB Amsterdam

The Netherlands

E-mail: e.j.s.plug@uva.nl

\footnotetext{
* We thank seminar and conference participants in Amsterdam, Aarhus, Braga and Gent for their comments and suggestions. We further thank Statistics Netherlands for their data support. Statistics Netherlands is not responsible for the analysis or interpretation of the data presented.
} 


\section{Introduction}

The economics of LGBT people, which stands for lesbians, gays, bisexuals and transgenders, is a relatively new field of study. It began to emerge in the late 1990s when lesbians and gays became better visible in larger surveys and administrative registers. Since then, economists have compared the earnings of lesbians and gays to that of straight women and men, and mostly found that lesbians earn more than straight women and gays earn less than straight men (Badgett, 1995; Klawitter and Flatt, 1998; Clain and Leppel, 2001; Berg and Lien, 2002; Black et al., 2003; Blandford, 2003; Plug and Berkhout, 2004, 2008; Frank, 2006; Carpenter, 2007; Elmsie and Tebaldi, 2007; Ahmed and Hammarstedt, 2010; Klawitter, 2015). In addition, economists began to apply various economic models to explain why lesbians and gays do not earn the same as other straight men and women; among these are models of gender role expectations, fertility-induced household specialization, prejudice-based discrimination models and differences in preferences (other than sexual preferences). ${ }^{1}$

One omission in this emerging sexual minority field is that transgenders (including transsexuals) have been largely ignored. Transgenders form a very small minority group, for which serious data limitations hinder empirical analysis. Unsurprising it may be, this omission is rather unfortunate. There are a number of reasons why we consider it interesting to examine the earnings of transgender workers. One reason is that we know little about the earnings of transgender workers, and how these compare to the earnings of other working women and men. Another reason is that we know little about how the earnings of transsexuals change when they change gender. Since transsexual workers remain the same workers with different genders at different times, transsexuals offer the unique opportunity to estimate gender effects in worker fixed effects earnings models, possibly providing insights on the origins of the gender gap.

In this paper we try to remedy this omission and examine the earnings of transsexual workers. Our data are taken from administrative registers on the Dutch labor force, where transsexual workers are defined as workers who administered a gender change somewhere between 2006 and 2012. Our data include several labor market outcomes and cover an extended period of time; as a result, we can compare the earnings of transsexuals before and after transition. In addition, we draw a one percent sample from the Dutch population, which allows us to compare the earnings of transsexual workers to the earnings of other women and men.

We are not the first to study transsexual workers. There are, as far as we know, two recent small scale studies that provide some evidence on transsexuals and their earnings. In the first study Schilt and Wiswall (2008) examine the earnings of transsexuals before and after their gender transitions using a worker fixed effects

\footnotetext{
${ }^{1}$ Examples of each are, respectively, Badgett (2003); Black, Sanders and Taylor (2007); Plug, Webbink and Martin (2014); Buser, Geijtenbeek and Plug (2015).
} 
model. With survey data that they collected from transsexuals at three different transgender conferences in the US and a transgender website, they find a marginal increase in the average earnings of female-to-male transsexual workers in response to their gender transitions, while average earnings for male-to-female transsexual workers fall. Their sample is very small and consists of 18 transsexual workers who change from male-to-female and 25 transsexual workers who change from female-to-male. Schilt and Wiswall acknowledge that their results are based on a small and selective sample and may not hold in larger and more representative samples of transsexual workers.

In the second study, researchers at Statistics Netherlands focus on inequality between transsexuals and heterosexuals and analyze their family incomes (Geerdinck et al., 2011). With a larger administrative data set of almost 500 transsexuals, they find that transsexuals have significantly lower family incomes than other women and men, which they attribute to differences in family structure and working status. In their study, they merely compare unadjusted family income levels without attention paid to the longitudinal nature of the data. In addition, there is some uncertainty about how informative family income is about individual earnings.

In this paper we add new evidence on the earnings of transsexual workers by literally building on the previous two papers; that is, we combine their strongest features and apply a worker fixed effects model using a larger administrative data set with longitudinal labor market information of transsexual workers. In particular, we examine earnings differentials between transsexual and heterosexual workers as well as earnings differentials of transsexual workers before and after the administrative gender change. When we explore some of the channels explaining earnings differentials, we make a distinction between two possible channels. One channel represents the gender channel; we may observe changes in earnings because of changes in gender, with women earning less than men, consistent with gender-based discrimination models or gender-based identity models (e.g. Darity and Mason 1998; Akerlof and Kranton 2000). The other channel represents the transition channel; we may observe changes in earnings because of the change itself, with transsexuals earning less after the gender change, consistent with sexual minority-based discrimination models or appearance-based discrimination models (Badgett, 2003; Hamermesh and Biddle, 1994). ${ }^{2}$

To preview our results, we find that transsexuals earn more than women and less than men, where female-to-male transsexuals earn less than other men and male-to-female transsexuals earn more than other women. We also find that earnings fall with about 20 percent for men who become women, against no significant change in earnings among women who become men. If we account

\footnotetext{
${ }^{2}$ Sexual minority-based discrimination models predict that transsexuals earn less after the transition because the transition itself reveals the worker's transsexuality to which prejudiced employers, fellow employees or consumers can respond. Also appearance-based discrimination models predict that transsexuals earn less after the change because the transition also involves changes to the worker's looks to which appearance-sensitive employers, fellow employees or consumers can respond.
} 
for differences in labor supply, we find that hourly earnings fall with about 12 percent for men who become women, against no change in hourly earnings among women who become men. If we decompose the hourly earnings differences into a gender and a transition component, we find evidence of a traditional gender gap of about 6 percent, while transsexuals experience an earnings loss of 6 percent after their gender transition. Taken together, these results suggest that the transition penalty offsets the earnings gain of women who become men but amplifies the earnings loss of men who become women.

The paper is organized as follows. Section II provides background information on transsexuals, some medical details involving sex reassignment surgery, and a discussion of the administrative data used in the analysis. Section III introduces our empirical strategy. Section IV presents our basic results, together with a number of robustness tests. Section V discusses possible interpretations of our results. Section VI concludes with a short summary and discussion.

\section{Background and data}

\section{A. Transsexuals}

Transsexuals are individuals who do not identify with the gender assigned to them at birth and wish to live as an individual of the opposite gender. In our data we identify transsexuals as individuals whose administrative gender change application has been approved and administered.

While we measure the administrative gender transition, the actual process of gender transition starts much earlier. In figure 1 we show the time line of the different stages in gender transition for a typical transsexual in the Netherlands. The first formal stage of gender transition consists of a psychological screening at one of the two Dutch hospitals who perform sex reassignment surgery. After a waiting period of about 10 months, a diagnostic stage follows in which a transsexual meets with psychology and psychiatry professionals in monthly sessions. This diagnostic stage mostly takes 3 to 9 months. If the diagnostic team has decided that a gender change is appropriate, it takes another 2 months before the so-called real-life experience stage begins. This is when gender transition becomes visible to others; that is, the transsexual receives hormone replacement therapy and dresses and lives by the new gender for at least a year. Once the real-life experience stage has passed successfully, the transsexual may apply for reassignment surgery, in which sexual organs of the old gender are removed and replaced with reconstructed sexual organs resembling more the sexual organs of the new gender. Once the reproductive organs of the old gender have been removed, which may take somewhere between 2 to 10 months, the transsexual can apply for an administrative change. Approval of the application goes through court and takes another 5 to 6 months. In all, this means that the worker's new gender becomes apparent to employers and fellow workers about 20 to 30 months before the administrative change takes place. 
In the Netherlands, transsexuals live in a country that is widely considered tolerant towards sexual minorities including transsexuals. According to the World Value Survey (WVS), which is a public survey data source with information on discriminatory attitudes against gays and lesbians collected in different countries across different times, the Netherlands is persistently ranked among the least discriminatory countries in the world (Andersen and Fetner 2008). These nondiscriminatory attitudes also work through institutions, policies and practices of daily life. For gays and lesbians, for example, the Netherlands has been the first country to allow for same-sex marriage. For transsexuals, sex reassignment surgery is generally paid for by the Dutch health care system. Transsexuals can, after sex reassignment surgery, officially register as the gender they identify with. Since 2014, this can be done free of charge at the local municipality and no longer requires sex reassignment surgery.

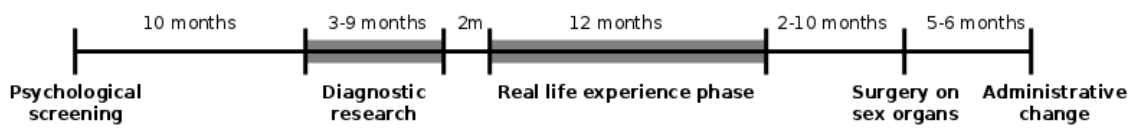

Note: Time (in months) from the first contact with the gender team up until administrative change.

Figure 1. Typical time Line For the transition process of a transsexual

\section{B. Data}

The data we use are a combination of multiple administrative registers held by Statistics Netherlands. The population register contains records on all individuals who are registered as resident of a Dutch municipality. Our baseline register includes all individuals who are 15 to 65 years old between 2003 and 2012 . Information on transsexual individuals and the year of their administrative gender change is only available from 2006 onwards. If we consider transsexuals who administered a gender change between 2006 and 2012, there are 502 transsexuals, of which 344 changed from male to female and 158 from female to male. In addition, we draw a one percent sample of all other individuals. Of these 98,821 individuals, 50,092 are men and 48,729 are women.

These samples have been merged to Dutch tax registers to get longitudinal labor market information. The employer tax register holds records on pre-tax annual labor earnings running from 2001 to 2012. Our measure of labor earnings captures annual earnings received from private and public sector employment. We use information for workers who worked at least 8 hours per week for 3 months per year.

There are two points about sample selection we need to take into account. First, 
our main analysis applies a fixed effects estimation strategy. This means that workers (including transsexual workers) must be observed at least twice between 2001 and 2012. Second, our main analysis compares the earnings of transsexual workers before and after the gender transition. There is some uncertainty about when the actual gender transition takes place. In our data, we observe a gender change in the year of the administrative gender transition. In the labor market, we believe that the gender change in the year the transsexual worker's gender becomes visible to employers and fellow employees is the more appropriate gender change. Without accurate information about the timing of the actual physical transformation, however, this means that we must make assumptions about the year of gender transition; that is, we rely on the time line of figure 1 and assume that the transition is gradual and starts more or less two years before the year of administrative gender change. In our sensitivity analysis, we will experiment with different transition windows to see how sensitive our transsexual estimates are.

In constructing our main analysis sample, we select workers who are employed in both 2003 and 2012. This means that all of the transsexual workers in our sample are observed before and after the administered gender change. We are left with a sample of 188 transsexual workers (115 male-to-female and 73 femaleto-male workers) and 51,225 non-transsexual workers (28,633 male and 22,592 female workers) with positive labor earnings in 2003 and 2012.

\section{Descriptive statistics}

Table 1 provides sample means for various demographic characteristics and labor market outcomes for men, women, male-to-female and female-to-male transsexuals for the years 2003 and 2012. As mentioned above, we choose these years in order to observe labor market outcomes of transsexuals before and after their transition period.

Four observations follow from this table. First, we find that the female-to-male transsexuals are almost 7 years younger than male-to-female transsexuals. This is consistent with the empirical evidence taken from the medical literature indicating that most female-to-male transsexuals have their sex reassignment surgery earlier than most male-to-female transsexuals (for example, De Cuypere et al. 2007). Second, we find huge gender differences in annual earnings of workers, with men earning almost 65 percent more than women. ${ }^{3}$ We attribute the larger part of these gender differences to women working in part-time jobs, as evidenced by working women working fewer hours than working men. ${ }^{4}$ Third, we find that the annual earnings of working transsexuals before as well as after transition are somewhere between the annual earnings of other men and women. And fourth,

\footnotetext{
${ }^{3}$ The 2012 log earnings difference of 0.5 translates into an earnings gap of 65 percent $\left(e^{0.5}-1 \simeq 0.65\right)$.

${ }^{4}$ Among OECD countries the Netherlands has an average female labor force participation, but by far the highest rate of part-time work; according to the OECD 61 percent of employed women in the Netherlands work part-time, against an OECD average of 26 percent (www.oecd.org).
} 
TABle 1 -Descriptive Statistics

\begin{tabular}{|c|c|c|c|c|c|c|c|c|}
\hline & $\begin{array}{c}\text { male } \\
\text { (i) }\end{array}$ & $\begin{array}{l}\text { male } \\
\text { to } \\
\text { female } \\
\text { (ii) }\end{array}$ & $\begin{array}{c}\text { female } \\
\text { to } \\
\text { male } \\
\text { (iii) }\end{array}$ & $\begin{array}{c}\text { female } \\
\text { (iv) }\end{array}$ & $\begin{array}{c}\text { male } \\
\text { vs } \\
\text { MtF } \\
(\mathrm{v})\end{array}$ & $\begin{array}{c}\text { male } \\
\text { vs } \\
\text { FtM } \\
\text { (vi) }\end{array}$ & $\begin{array}{l}\text { female } \\
\text { vs } \\
\text { MtF } \\
\text { (vii) }\end{array}$ & $\begin{array}{c}\text { female } \\
\text { vs } \\
\text { FtM } \\
\text { (viii) }\end{array}$ \\
\hline Age 2003 & 36.35 & 37.84 & 31.26 & 35.04 & 0.09 & 0.00 & 0.00 & 0.00 \\
\hline Log earnings 2003 & 10.14 & 10.18 & 9.64 & 9.59 & 0.59 & 0.00 & 0.00 & 0.56 \\
\hline Log earnings 2012 & 10.54 & 10.31 & 10.11 & 10.04 & 0.00 & 0.00 & 0.00 & 0.29 \\
\hline Working hours 2003 & 36.74 & 37.29 & 28.29 & 32.28 & 0.41 & 0.00 & 0.00 & 0.00 \\
\hline Working hours 2012 & 37.87 & 35.51 & 29.63 & 35.76 & 0.00 & 0.01 & 0.00 & 0.00 \\
\hline Observations & 28,633 & 115 & 73 & 22,592 & & & & \\
\hline
\end{tabular}
Note: In columns (v) to (viii) we test for statistical difference or similarity in group characteristics of
male versus male-to-female workers, male versus female-to-male workers, female versus male-to-female workers and female versus female-to-male workers. Low p-values indicate a significant difference.

we find only a modest increase in annual earnings for male-to-female workers relative to the large increase in annual earnings we observe for all other workers (including female-to-male workers) between 2003 and 2012.

\section{Empirical strategy}

As the starting point of our empirical analysis on the earnings of transsexual workers, we take a cross-sectional perspective and specify an earnings equation of the form

$$
Y_{i t}=\alpha T_{i}+\beta F_{i}+\gamma A F T E R_{i t}+\delta C O H O R T_{i}+\lambda_{t}+\varepsilon_{i t},
$$

where $Y_{i t}$ stands for the logarithm of annual earnings of worker $i$ in year $t, T_{i}$ is a transsexual dummy variable that takes the value one if the worker is a transsexual worker, $F_{i}$ is a gender dummy that takes the value one if the non-transsexual worker $i$ is female, AFTER $R_{i t}$ is a dummy variable that takes the value one after the transsexual worker $i$ has had sex reassignment surgery and registered the new gender in year $t, C O H O R T_{i}$ is a full set of dummy variables for the worker's birth year, $\lambda_{t}$ is a full set of year dummies for the year the worker is observed, and $\varepsilon_{i t}$ represents all those unobservable components that vary across workers and time. The parameter $\alpha$ indicates how the earnings of transsexuals before the administrative gender change compare to other men. The parameter $\gamma$ indicates how the earnings of transsexuals compare before and after the administrative gender change.

Longitudinal data allow us to include worker fixed effects $\mu_{i}$ in (1), which is the standard way to account for those observable and unobservable components that vary across workers but not across time. The earnings equation then takes 
the form

$$
Y_{i t}=\gamma A F T E R_{i t}+\mu_{i}+\lambda_{t}+\varepsilon_{i t}
$$

It is easy to see that a longitudinal earnings equation with worker fixed effects is no longer informative about how the earnings of transsexual workers compare to those of other workers; that is, the worker fixed effects absorb the variables $T_{i}, F_{i}$ and $\mathrm{COHORT}_{i}$.

The earnings equation displayed in (1) and (2) can be generalized to exploit the differences between male-to-female and female-to-male workers. In particular, we can relax the imposed symmetry between female-to-male and male-to-female workers and allow for different earnings changes for workers who change from male to female and from female to male. In a cross-sectional setup, the earnings equation is given by

$$
\begin{aligned}
Y_{i t}=\alpha_{1} \text { FtM }_{i}+\alpha_{2} \text { MtF }_{i}+\beta F_{i}+\gamma_{1} \text { AFTER }_{i t} \text { FtM }_{i} \\
+ \\
+\gamma_{2} \text { AFTER }_{i t} M t F_{i}+\delta \text { COHORT } \\
i
\end{aligned}
$$

where dummy $M t F_{i}$ takes the value one if the worker is a female-to-male transsexual, $F t M_{i}$ takes the value one if the worker is a female-to-male transsexual, while the interaction dummies take the value one after the male-to-female and female-to-male workers have had surgery and administered their new gender in year $t$. If we add worker fixed effects, the earnings equation turns into

$$
Y_{i t}=\gamma_{1} A F T E R_{i t} F t M_{i}+\gamma_{2} A F T E R_{i t} M t F_{i}+\mu_{i}+\lambda_{t}+\varepsilon_{i t} .
$$

There are two other points to note about these equations. First, these earnings specifications are informative about gender effects; that is, we obtain consistent gender effect estimates in the worker fixed effects model in (4) if we assume that gender is the only factor that is changing for transsexual workers. In this case a negative $\gamma_{1}$ and positive $\gamma_{2}$ would indicate that there is a penalty for becoming a woman and a premium for becoming a man. Second, we have included (but for notational convenience not reported) separate transition year dummies for the two years preceding the year of the administrative gender change. As we already mentioned, there is some uncertainty about when the actual gender transition takes place. We argue that the gender transition is a gradual process which takes about two years up to year of renewed gender registration. In our baseline regression models we therefore added these two pre-transition year dummies, so that the earnings observed for these years do not influence our transsexual estimates of interest. In Sections 4 and 5 we offer a less restrictive parameter interpretation and test how sensitive our results are to alternative transition windows. 
TABle 2-The ANNUAL EARNINGS OF TRANSSEXUAL WORKERS

\begin{tabular}{|c|c|c|c|c|}
\hline & $\begin{array}{l}\text { OLS } \\
\text { (i) }\end{array}$ & $\begin{array}{l}\text { FE } \\
\text { (ii) }\end{array}$ & $\begin{array}{l}\text { OLS } \\
\text { (iii) }\end{array}$ & $\begin{array}{l}\text { FE } \\
\text { (iv) }\end{array}$ \\
\hline Non-transsexual female $(\beta)$ & $\begin{array}{l}-0.52^{* * *} \\
(0.00)\end{array}$ & & $\begin{array}{l}-0.52^{* * *} \\
(0.00)\end{array}$ & \\
\hline Transsexual, before $(\alpha)$ & $\begin{array}{l}-0.28^{* * *} \\
(0.05)\end{array}$ & & & \\
\hline Female-to-male, before $\left(\alpha_{1}\right)$ & & & $\begin{array}{l}-0.48^{* * *} \\
(0.06)\end{array}$ & \\
\hline Male-to-female, before $\left(\alpha_{2}\right)$ & & & $\begin{array}{l}-0.05 \\
(0.05)\end{array}$ & \\
\hline Transsexual, change $(\gamma)$ & $\begin{array}{l}-0.07 \\
(0.04)\end{array}$ & $\begin{array}{l}-0.11^{* * *} \\
(0.04)\end{array}$ & & \\
\hline Female-to-male, change $\left(\gamma_{1}\right)$ & & & $\begin{array}{c}0.11 \\
(0.07)\end{array}$ & $\begin{array}{c}0.07 \\
(0.07)\end{array}$ \\
\hline Male-to-female, change $\left(\gamma_{2}\right)$ & & & $\begin{array}{l}-0.16^{* * *} \\
(0.06)\end{array}$ & $\begin{array}{l}-0.23^{* * *} \\
(0.05)\end{array}$ \\
\hline \multicolumn{5}{|l|}{ Controls variables: } \\
\hline Year of observation dummies & $\checkmark$ & $\checkmark$ & $\checkmark$ & $\checkmark$ \\
\hline Individual dummies & & $\checkmark$ & & $\checkmark$ \\
\hline Observations & 593,165 & 593,165 & 593,165 & 593,165 \\
\hline$R^{2}$ & 0.34 & 0.76 & 0.34 & 0.76 \\
\hline $\begin{array}{l}\text { Note: The dependent variable is ar } \\
\text { are being a transsexual worker befo } \\
\text { regressions are tabulated in colum } \\
\text { The worker fixed effects regression } \\
\text { include year dummies. Standard } \\
\text { significant at } 10 \% \text { level; }{ }^{* *} \text { signific }\end{array}$ & $\begin{array}{l}\text { asured in l } \\
\text { the effect } \\
\text { these regre } \\
\text { columns c } \\
\text { d at the in } \\
* * * \text { signific }\end{array}$ & $\begin{array}{l}\text { The ind } \\
\text { ransition } \\
\text { ms includ } \\
\text { mns (ii) a } \\
\text { idual leve }\end{array}$ & $\begin{array}{l}\text { endent var } \\
\text { hange). Th } \\
\text { cohort anc } \\
\text { (iv); these } \\
\text { and betwee }\end{array}$ & $\begin{array}{l}\text { bles of int } \\
\text { cross-sect } \\
\text { year dum } \\
\text { egressions } \\
\text { parenthes }\end{array}$ \\
\hline
\end{tabular}

\section{Main results}

\section{A. The annual earnings of transsexuals}

Table 2 contains the main estimates of the relationship between annual labor earnings (measured in logarithmic form) and being a transsexual worker, controlling for year and cohort fixed effects. In columns (i) and (iii) we report the results of equations (1) and (3) using least squares estimation. These results allow us to compare the earnings of transsexuals to the earnings of other workers. In column (i) we find that before transition transsexuals earn less than other men but more than other women. ${ }^{5}$ In column (iii) we make a distinction between the effect of being a male-to-female and female-to-male worker and find that before

${ }^{5}$ The gender earnings gap of 52 percent we find is large but comparable to most other gender gap estimates that have appeared in earnings studies in the Netherland. The large estimates are typically attributed to the large share of women working part-time (Bosch and van der Klaauw, 2012). In Table 4 we confirm this. 
transsexuals change gender the earnings differences are most pronounced between male-to-female and female-to-male workers, with an earnings difference of almost 55 percent $\left(e^{0.43}-1 \simeq 0.54\right)$. The order of magnitude suggests that the earnings of transsexuals before transition resemble most the earnings of the workers with whom they share their birthgender.

In columns (ii) and (iv) we report the results of equations (2) and (4) that include worker fixed effects. These results allow us to (better) compare the earnings of transsexuals before and after the gender change. In columns (i) and (ii) we find that transsexuals earn 7 to 11 percent less after the gender transition. In columns (iii) and (iv) we find that the negative effect observed after the gender change is primarily driven by workers who change from male to female. They earn 16 to 23 percent less after the gender change. Workers who change from female to male earn more after the gender change but this effect is small and not statistically different from zero. These results are robust to the inclusion of worker fixed effects. ${ }^{6}$

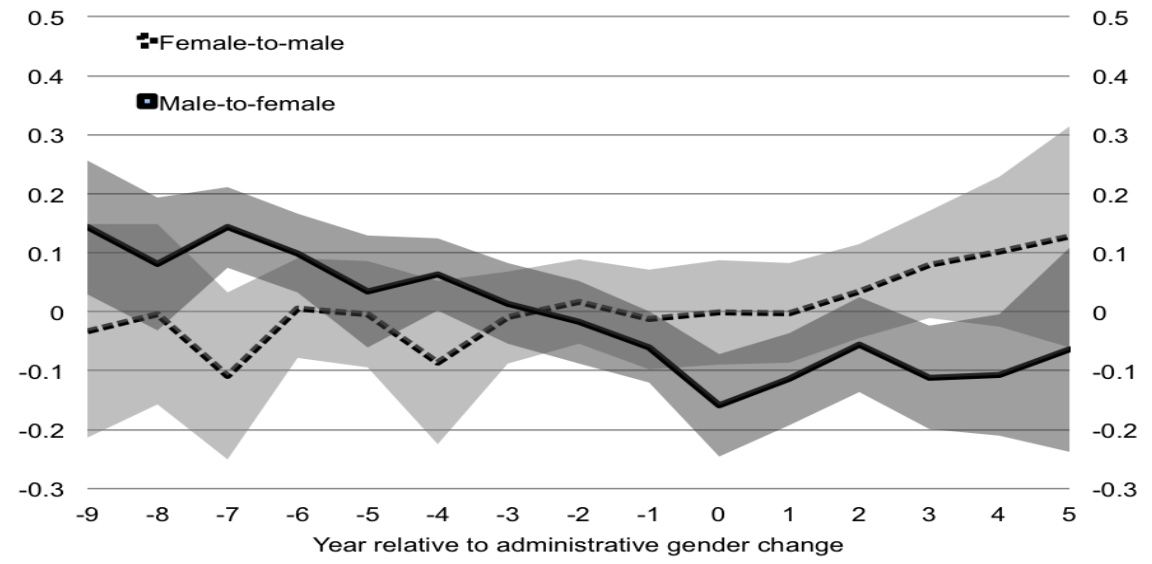

Note: The graphs contain log earnings of female-to-male and male-to-female workers by year relative to administrative change, after controlling for year and individual fixed effects. Actual transition occurs one and two years before the administrative change. The shaded areas are 95 percent confidence intervals.

Figure 2. LOG EARNINGS OF TRANSSEXUALS BY YEAR RELATIVE TO TRANSITION

Figure 2 plots how the annual labor earnings of male-to-female and female-tomale workers (conditional on year and individual fixed effects) change over time relative to the year in which the new gender was registered. It shows in more detail how the earnings of transsexuals evolve over time. The average annual earnings

\footnotetext{
${ }^{6}$ We have also tried allowing for cohort-specific linear time trends. Our results are insensitive to the inclusion of these extra variables; that is, we find fixed effects estimates of $0.01(0.06)$ and $-0.19(0.05)$ for female-to-male and male-to-female workers (with standard errors in parentheses) suggesting that the earnings of female-to-male workers do not change, whereas the earnings of male-to-female workers fall after the gender transition.
} 
of working female-to-male transsexuals follow an almost horizontal line, with a modest increasing trend starting after the year of transition. The average annual earnings of working male-to-female transsexuals begin trending down approaching the year of transition, but come to a near standstill after the year of transition. Particularly revealing is the earnings comparison between male-to-female and female-to-male workers. We see gender earnings gaps before as well as after the year of transition; that is, male-to-female workers earn more than femaleto-male workers in pre-transition years, but less than female-to-male workers in post-transition years. About two years before the administrative transition, we see that they earn about the same, which supports our original choice of the transition window.

TABle 3-Sensitivity Regressions using alternative transition Windows

\begin{tabular}{|c|c|c|c|c|c|}
\hline & $\begin{array}{l}\text { Baseline } \\
\text { (i) }\end{array}$ & $\begin{array}{l}\text { Short } \\
\text { (ii) }\end{array}$ & $\begin{array}{l}\text { Long } \\
\text { (iii) }\end{array}$ & $\begin{array}{l}\text { Early } \\
\text { (iv) }\end{array}$ & $\begin{array}{l}\text { Late } \\
\text { (v) }\end{array}$ \\
\hline Female-to-male, change & $\begin{array}{c}0.07 \\
(0.07)\end{array}$ & $\begin{array}{c}0.06 \\
(0.06)\end{array}$ & $\begin{array}{c}0.10 \\
(0.08)\end{array}$ & $\begin{array}{c}0.05 \\
(0.07)\end{array}$ & $\begin{array}{c}0.11 \\
(0.07)\end{array}$ \\
\hline Male-to-female, change & $\begin{array}{l}-0.23^{* * *} \\
(0.05)\end{array}$ & $\begin{array}{l}-0.20^{* * *} \\
(0.04)\end{array}$ & $\begin{array}{l}-0.24 * * * \\
(0.06)\end{array}$ & $\begin{array}{l}-0.22^{* * *} \\
(0.05)\end{array}$ & $\begin{array}{l}-0.19^{* * *} \\
(0.06)\end{array}$ \\
\hline \multicolumn{6}{|l|}{ Transition window: } \\
\hline Last pre-transition year & $\tau-3$ & $\tau-2$ & $\tau-4$ & $\tau-5$ & $\tau-1$ \\
\hline First post-transition year & $\tau$ & $\tau-1$ & $\tau+1$ & $\tau-2$ & $\tau+2$ \\
\hline Observations & 593,165 & 593,165 & 593,165 & 593,165 & 593,165 \\
\hline$R^{2}$ & 0.76 & 0.76 & 0.76 & 0.76 & 0.76 \\
\hline \multicolumn{6}{|c|}{$\begin{array}{l}\text { Note: The dependent variable is log annual earnings. The independent variables are the effects of } \\
\text { transition for a male-to-female and female-to-male worker. All regressions include individual fixed effects } \\
\text { and year dummies. The transition windows are given with respect to year of administrative change } \tau \text {. } \\
\text { To account for different transition windows, we add transition year dummies for the transition years } \\
\text { so that the earnings observed for these years do not influence our transsexual estimates of interest. } \\
\text { Standard errors are clustered at the individual level and between parentheses; }{ }^{*} \text { significant at } 10 \% \text { level; } \\
{ }^{* *} \text { significant at } 5 \% \text { level; }{ }^{* * *} \text { significant at } 1 \% \text { level. }\end{array}$} \\
\hline
\end{tabular}

Table 3 contains a number of additional robustness checks to see whether our transsexual earnings results hold up against alternative gender transition windows. In our baseline regressions we assume that the timing of visible gender transition (that is, visible to others) starts two years before the year of administrative gender change. As we already mentioned, we do not know the exact timing of the gender transition, which may lead to biased earnings results. In particular, we are concerned that the transition window we choose can be too short (and takes more than two years) or starts earlier (and actually begins three years prior to the administrative gender change) and lead to underestimated before/after differences due to pre-transition earnings measures that are wrongly classified. To check this, we have run our transsexual regression models under varying transition periods. For reference purposes, the first column repeats our baseline results of a two year transition period. The next columns show results for 
a short transition period of zero years (column (ii)), a long period of four years (column (iii)), a two year period shifted two years backwards in time (column (iv)), or two years forward (column (v)). ${ }^{7}$ The last year of the pre-transition period and the first year of the post-transition period are reported at the bottom of each column. We find that none of the alternative estimates are significantly distinguishable from the baseline estimates. The estimated effects for male-tofemale workers are all substantially negative (ranging from 19 to 24 percent) and statistically significant. The estimated effects for female-to-male workers are all positive (ranging from 5 to 11 percent) and statistically insignificant. All these estimates suggest that assumptions on the exact timing of gender transition have little effect on our results.

\section{B. The labor supply of transsexuals}

Labor supply is another important labor market outcome in which transsexuals may differ from other men and women. To examine labor supply, we re-estimate equations (3) and (4) and switch the dependent variable to labor supply outcomes. The labor supply outcomes we consider measure the decision to work (extensive margin) and the number of hours worked in a typical week (intensive margin). Table 4 presents these labor supply results.

In columns (i) and (ii) we focus on the probability of working among an extended sample of working and nonworking individuals. As expected, we find that women work considerably less than men. When we compare transsexuals to other men and women, we find that transsexuals are less likely to work than non-transsexual men as well as non-transsexual women. In comparison to men, the estimated probabilities of working for transsexuals before transition are 12 percent lower for female-to-male transsexuals and 19 percent lower for male-to-female transsexuals. When we compare transsexuals before and after the gender transition, we find transsexuals experience a 3 to 5 percent rise in the probability of working when they change from female to male, whereas they experience a 7 to 8 percent fall in probability of working when they change from male to female. While the effects are not statistically different from zero for female-to-male transsexuals, the pattern is consistent with transsexuals working less when they live as female.

In columns (iii) and (iv) we turn to weekly working hours among those who work. We find that, on average, transsexuals before transition work fewer hours than non-transsexual men but more hours than non-transsexual women. These differences in working hours are largely driven by female-to-male workers. The hours of work comparison before and after the gender change shows that transsexual workers work about 2 hours less when they change from male to female, but work about 2 hours more when they change from female to male. Again,

\footnotetext{
${ }^{7}$ Let $\tau$ be the year of the administrative gender change of a transsexual worker. In our baseline model we include separate transition year dummies for years $\tau-2$ and $\tau-1$, so that the earnings observed for these years do not influence our transsexual estimates of interest. In this case, the last year of the pre-transition period is $\tau-3$, and the first year of the post-transition period is $\tau$.
} 


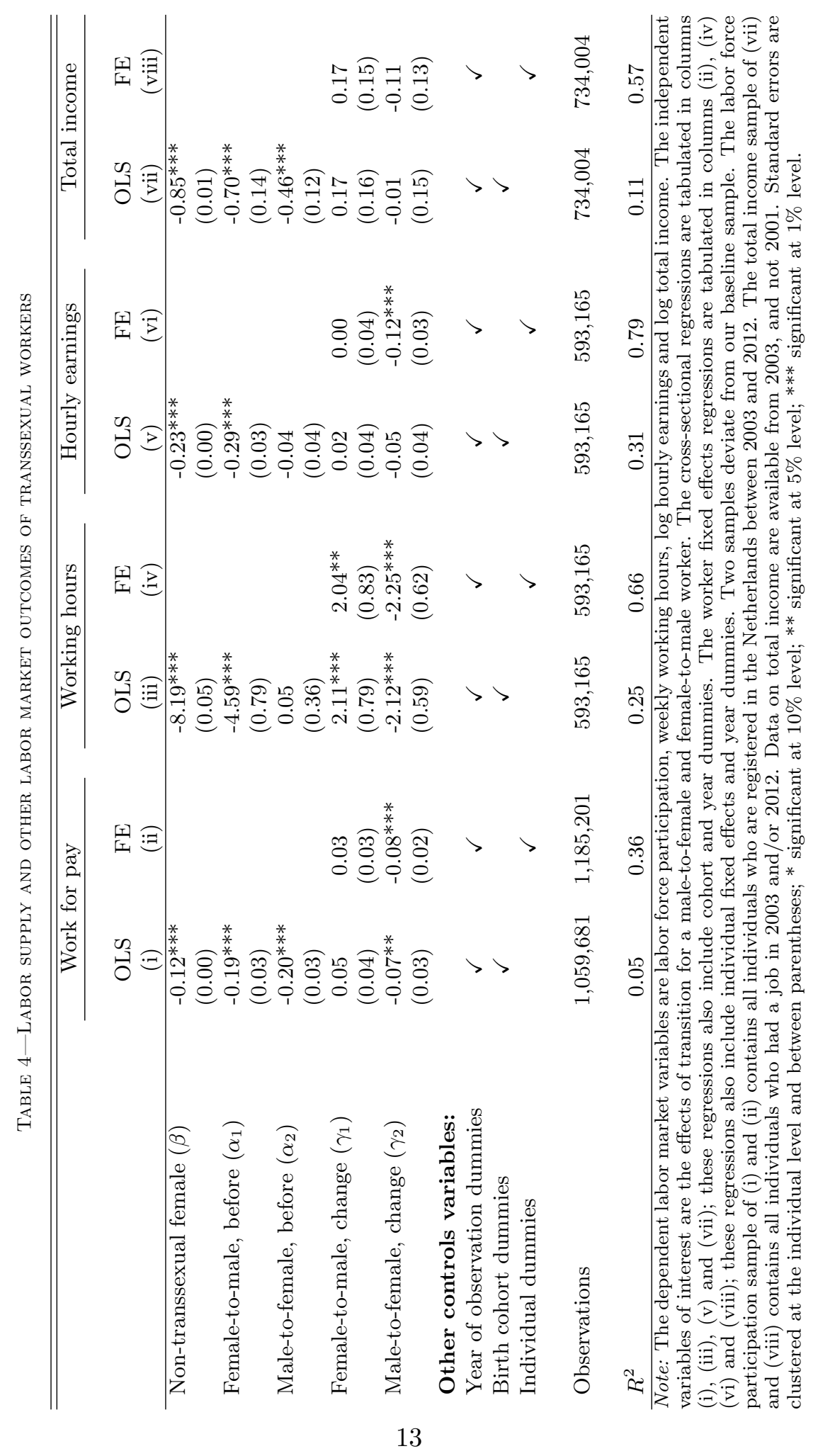


these labor supply fixed effects results are consistent with transsexuals working less as female.

\section{Why do annual earnings of transsexuals change?}

To further explore whether the rise and fall in annual earnings are driven by female-to-male workers working more and male-to-female workers working less, we analyze the relationship between hourly labor earnings and being transsexual, controlling for year and either cohort or individual fixed effects. If it is the case that differences in annual earnings arise because of differences in labor supply and not because of something else, the fixed effects estimates attached to the interacted female-to-male and male-to-female dummies should be zero. In the fixed effects specification in column (vi), however, we find that that hourly earnings significantly fall for men who become women and remain more or less the same for women who become men. This means that the changes in hours worked because of the transition can only partly explain the changes in annual earnings.

Because we find that changes in annual earnings are due to changes in labor supply as well as changes in hourly compensation, we also consider another explanation for the transsexual gap in earnings (which is best observed among those transsexual workers who change from men to women). In particular, we ask ourselves whether transsexual workers after the gender change sort into more tolerating but lower paid occupations. Information on private and public sector jobs is available in part of our data. If we believe that public sector jobs are, on average, more tolerating but lower paid occupations, we can check the extent to which differences in earnings may come from transsexual workers sorting into public sector occupations. While not reported in the table, our least-squares and fixed effects estimates suggest that transsexuals are not more likely to work in the public sector after the gender transition. ${ }^{8}$

\section{Selective labor market withdrawal}

While it is interesting to see that male-to-female transsexuals face significantly lower participation rates after the transition, it also raises the issue of sample selection. We observe earnings (and hours) for only those transsexuals and nontranssexuals who work. But if male-to-female transsexuals decide to stop working when earnings fall below some reservation threshold, our sample selection rules (transsexual workers, including male-to-female transsexuals must work both before and after the gender change) ignore selective labor market withdrawal and may indicate that the fall in labor force participation we estimate for male-tofemale transsexuals after the transition is an underestimate.

\footnotetext{
${ }^{8}$ In linear probability fixed effects models with public sector job as outcome we find fixed effects estimates of $0.00(0.04)$ and $0.01(0.04)$ for female-to-male and male-to-female workers (with standard errors in parentheses).
} 
To check whether selective labor market withdrawal is affecting our earnings results, we construct an annual income measure for working and nonworking individuals and examine whether the earnings results change when we re-estimate equations (3) and (4) using annual income as dependent variable on an enlarged sample of working and nonworking individuals (who were working for pay in 2003 and/or 2012). Our measure of annual income is taken from the income tax register and includes self-reported labor income from private employment, public employment and self-employment as well as non-labor income from social benefits, such as unemployment benefits and pensions, over the period 2003-2012. Table 4 reports these results in columns (vii) and (viii).

When we use annual income of working and nonworking transsexuals as our outcome measure, we keep finding that after the gender transition male-to-female transsexuals have less income and female-to-male transsexuals have more income. In comparison to the annual earnings results, we find that the income penalty for those who change from male to female is smaller, whereas the income premium for those who change from female to male appears larger. Since these differences in income are rather imprecisely estimated, we cannot draw firm conclusions about selective labor market withdrawal of transsexuals and their impact on the annual earnings of transsexuals.

\section{Interpreting results}

Two consistent earnings findings emerge from the empirical analysis on trans-

sexuals. First, we find that men who become women experience a significant fall in labor earnings after the gender transition. Second, we find that the labor earnings of women who become men hardly change. If there is any change, we find that women who become men earn somewhat more after the gender transition. In addition, these findings hold for annual labor earnings as well as for hourly labor earnings. What causes these particular labor market patterns for transsexual workers?

While it is always difficult to interpret reduced-form estimates, we consider two plausible mechanisms that can predict the observed changes in earnings. The first mechanism is a gender mechanism; that is, transsexuals are treated differently or behave differently when they turn female. It is possible that transsexuals face gender discrimination or decide to follow the prevailing norm about what is considered appropriate for women and adapt their occupations, earnings level and work hours to those of other women (Akerlof and Kranton, 2000). The second mechanism is a post-transition mechanism; that is, transsexuals are treated differently after the gender transition, regardless of their gender. It is possible that transsexuals face appearance-based discrimination and choose to work elsewhere to avoid possible negative responses about their less standard appearance, being either a tall, square-jawed woman or a small, round-faced man (Hamermesh and Biddle, 1994). It is also possible that transsexuals experience a labor market that discriminates against sexual minorities, once their transsexuality has been 
revealed (Badgett, 2003).

We can differentiate between the hypothesized gender and transition penalties if we assume that all transsexual workers are exposed to different combinations of the same gender and transition penalties. To put it more formally, we can reformulate equation (4) and write the parameters $\gamma_{1}$ and $\gamma_{2}$ as functions $\gamma_{F}$ and $\gamma_{T}$, where $\gamma_{F}$ and $\gamma_{T}$ stand for the gender and transition penalties. The model we have in mind is

$$
Y_{i t}=\gamma_{F} F T_{i t}+\gamma_{T} T T_{i t}+\mu_{i}+\lambda_{t}+\varepsilon_{i t}
$$

where $F T$ and $T T$ are female and post-transition dummies. In this setup, workers who change from male to female experience a fall in earnings because of reenforcing gender and transition penalties $\left(\gamma_{2}=\gamma_{T}+\gamma_{F}\right)$, whereas workers who change from female to male earn about as much before and after the transition because the earnings gain of becoming a man offsets the earnings loss of revealing ones transsexuality $\left(\gamma_{1}=\gamma_{T}-\gamma_{F}\right)$.

TABle 5-SEPARATING GENDER EFFECTS FROM TRANSITIONS EFFECTS

\begin{tabular}{|c|c|c|c|c|c|}
\hline & $\begin{array}{l}\text { Annual } \\
\text { income } \\
\text { (i) }\end{array}$ & $\begin{array}{l}\text { Work } \\
\text { for pay } \\
\text { (ii) }\end{array}$ & $\begin{array}{c}\text { Working } \\
\text { hours } \\
\text { (iii) }\end{array}$ & $\begin{array}{l}\text { Hourly } \\
\text { earnings } \\
\text { (iv) }\end{array}$ & $\begin{array}{c}\text { Total } \\
\text { income } \\
(\mathrm{v})\end{array}$ \\
\hline Gender effect $\gamma_{F}$ & $\begin{array}{l}-0.12^{* * *} \\
(0.04)\end{array}$ & $\begin{array}{l}-0.05^{* * *} \\
(0.02)\end{array}$ & $\begin{array}{l}-2.15^{* * *} \\
(0.52)\end{array}$ & $\begin{array}{l}-0.06^{* *} \\
(0.02)\end{array}$ & $\begin{array}{l}-0.14 \\
(0.10)\end{array}$ \\
\hline Transition effect $\gamma_{T}$ & $\begin{array}{l}-0.10^{* *} \\
(0.04)\end{array}$ & $\begin{array}{l}-0.03 \\
(0.02)\end{array}$ & $\begin{array}{l}-0.11 \\
(0.52)\end{array}$ & $\begin{array}{l}-0.06^{* *} \\
(0.02)\end{array}$ & $\begin{array}{c}0.03 \\
(0.10)\end{array}$ \\
\hline
\end{tabular}

Note: The dependent labor supply variables are labor force participation, weekly working hours, log hourly earnings, log annual earnings and log total income. The independent variables of interest are dummy variables administered gender and post-transition period. The worker fixed effects regressions are based on equation (5). Standard errors are clustered at the individual level and between parentheses; * significant at $10 \%$ level; $* *$ significant at $5 \%$ level; *** significant at $1 \%$ level.

Table 5 reports the gender and transition estimates that correspond to the worker fixed effects specification in equation (5). All the estimates indicate that transition effects are smaller, not larger, than the gender effects. If we consider the labor supply outcomes, we find that the labor supply responses are almost entirely driven by differences in gender; that is, transsexuals work less (on both extensive and intensive margins) when they live as female. This partly explains why transsexuals have lower annual earnings (as well as lower total income) as female. If we consider hourly earnings, however, we find that gender and transition effects are roughly equal. This means that transsexuals who change from men to women are penalized twice: once for becoming a women, and once for disclosing their transsexuality. ${ }^{9}$

\footnotetext{
${ }^{9}$ Obviously, this interpretation relies on the assumption that gender and transition penalties do not vary for male-to-female and female-to-male transsexuals. In case others discriminate male-to-female
} 


\section{Conclusion}

This is one of the first empirical papers to examine the earnings of transsexual workers. Using longitudinal data taken from various administrative registers in The Netherlands, we find that before transition, female-to-male workers have earnings that are similar to other female workers, while male-to-female workers have similar earnings as other men. In addition, we find that male-to-female transsexual workers (but not female-to-male transsexual workers) earn about 2025 percent less when they are of the female gender. This earnings penalty is robust to the inclusion of worker fixed effects, alternative assumptions about the timing of transition, as well as labor supply differences in working hours and selective labor participation.

When we turn to possible mechanisms that can explain a substantial earnings penalty for becoming a woman and a modest premium for becoming a man, we show that the transsexual earnings patterns in our data are consistent with a (discriminating) labor market in which transsexual workers are paid less as disclosed transsexual as well as being a registered female.

While our study clearly contributes to a small but growing economics literature on sexual minorities, we realize that the earnings results for transsexuals with corresponding interpretations must be treated with care; that is, our results may prove difficult to generalize to other populations in other countries. Concerns about other populations, we believe, are warranted. If gender effects are estimated on other samples than transsexual men and women, it is clear that corresponding gender estimates need not be equal. Concerns about other countries, however, seem misplaced. With an unrepresentative sample of transsexuals in the United States, Schilt and Wiswall (2008) find earnings patterns similar to those in our study.

\section{REFERENCES}

Ahmed, Ali M., and Mats Hammarstedt. 2010. "Sexual orientation and earnings: A register data-based approach to identify homosexuals." Journal of Population Economics, 23: 835-49.

Akerlof, George, and Rachel Kranton. 2000. "Economics and identity." The Quarterly Journal of Economics, 115(3): 715-753.

Badgett, M.V. Lee. 1995. "The wage effects of sexual orientation discrimination." Industrial and Labor Relations Review, 48: 726-39.

Badgett, M.V. Lee. 2003. Money, myths, and change: The economic lives of lesbians and gay men. University of Chicago Press.

workers more than female-to-male workers in the same way as others discriminate gays more than lesbians, the fixed penalty assumption no longer holds leading to gender effect estimates that are too high and transition effect estimates that are too low. Similar biases occur if male-to-female workers less likely pass as female workers than female-to-male workers pass as male workers. 
Berg, Nathan C., and Donald Lien. 2002. "Measuring the effect of sexual orientation on income: Evidence of discrimination?" Contemporary Economic Policy, 20: 394-414.

Black, Dan A., Hoda R. Makar, Seth G. Sanders, and Lowell J. Taylor. 2003. "The effects of sexual orientation on earnings." Industrial and Labor Relations Review, 56: 449-69.

Black, Dan A., Seth G. Sanders, and Lowell J. Taylor. 2007. "The economics of lesbian and gay families." Journal of Economic Perspectives, 21(Spring): 53-70.

Blandford, John M. 2003. "The nexus of sexual orientation and gender in the determination of earnings." Industrial and Labor Relations Review, 56: 622-42.

Bosch, Nicole, and Bas van der Klaauw. 2012. "Analyzing female labor supply: Evidence from a Dutch tax reform." Labour Economics, 19(3): 271280.

Buser, Thomas, Lydia Geijtenbeek, and Erik Plug. 2015. "Do gays shy away from competition? Do lesbians compete too much?" University of Amsterdam.

Carpenter, Christopher S. 2007. "Revisiting the income penalty for behaviorally gay men: Evidence from NHANES III." Labour Economics, 14: 24-34.

Clain, Suzanne H., and Karen Leppel. 2001. "An investigation into sexual orientation discrimination as an explanation for wage differences." Applied Economics, 33: 37-47.

Darity, William A, and Patrick L Mason. 1998. "Evidence on discrimination in employment: codes of color, codes of gender." The Journal of Economic Perspectives, 63-90.

De Cuypere, G., M. Van Hemelrijck, A. Michel, B. Carael, G. Heylens, R. Rubens, P. Hoebeke, and S. Monstrey. 2007. "Prevalence and demography of transsexualism in Belgium." European Psychiatry, 22(3): 137 - 141.

Elmsie, Bruce, and Edinaldo Tebaldi. 2007. "Sexual orientation and labor market discrimination." Journal of Labor Research, 28: 436-53.

Frank, Jeff. 2006. "Gay glass ceilings." Economica, 73: 485-508.

Geerdinck, Marleen, Linda Muller, Carlijn Verkleij, and Caroline van Weert. 2011. "Transseksuelen in Nederland Is er sprake van ongelijkheid?" Statistics Netherlands.

Hamermesh, Daniel, and Jeff Biddle. 1994. "Beauty and the labor market." American Economic Review, 84: 1174-1194. 
Klawitter, Marieka. 2015. "Meta-Analysis of the Effects of Sexual Orientation on Earnings." Industrial Relations: A Journal of Economy and Society, 54(1): 4-32.

Klawitter, Marieka M., and Victor Flatt. 1998. "The effects of state and local anti-discrimination policies for sexual orientation." Journal of Policy Analysis and Management, 17: 658-86.

Plug, Erik, and Peter Berkhout. 2004. "Effects of sexual preferences on earnings in the Netherlands." Journal of Population Economics, 17: 117-31.

Plug, Erik, and Peter Berkhout. 2008. "Sexual orientation, disclosure and earnings." Institute for the Study of Labor, Bonn Germany IZA DP 3290.

Plug, Erik, Dinand Webbink, and Nick Martin. 2014. "Sexual orientation, prejudice, and segregation." Journal of Labor Economics, 32(1): 123-159.

Schilt, Kristen, and Matthew Wiswall. 2008. "Before and after: Gender transitions, human capital, and workplace experiences." The BE Journal of Economic Analysis 85 Policy, 8(1): article 39. 